\title{
Performance Evaluation in Private Schools: a Case Study of the Educators School
}

\author{
Shakeel Sarwar \\ Lecturer, Department of Management Sciences \\ The Islamia University of Bahawalpur, Pakistan
}

Usama Awan

Lecturer, Department of management sciences, COMSATS Institute of Information

Technology, Vehari Pakistan.

Email.awan.usama@gmail.com

Mehak Nazir (Corresponding author)

MS Scholar, The Islamia University of Bahawalpur

Bahawalpur, Pakistan

E-mail: mehak.nazeer@gmail.com

Accepted: December 17, 2013

doi:10.5296/ jpag.v3i4.4934 URL: http://dx.doi.org/10.5296/ jpag.v3i4.4934

\begin{abstract}
Performance appraisal system is of important apprehension of any organization while administrating its human resources. The purpose of this paper is to evaluate the performance appraisal system for teachers in private schools and elaborate the problems align with this system. The Educators School has been taken as a case study. A quantitative research approach has been applied which consist on a self administered questionnaire to get primary data for exploring different parts of current performance appraisal system and perceptions of teachers regarding performance appraisal approaches in their school. Research results shows that The Educators School is using performance appraisal system that is closely related with traditional ACR (Annual Confidential Report) conducted annually. This study is conducted on a small level only on one franchise of the school system with small sample size.
\end{abstract}


Researchers suggest that school administration should provide continuous feedback to their teachers and a solution to overcome their weaknesses and this system should only be used for performance improvement purpose.

Keywords: Performance appraisal, ACR, Performance Development

\section{Introduction}

Organization is made up of group of people who run and steer that organization and also set goals and realize objectives. So an organization's performance depends on the sum total of its employee's performance. Thus for an organization success it is compulsory to enhance its ability to accurately measure the member's performance and use it factually to enrich them as an essential resource (Biswajeet 2009). In this present era organizations have to make sure the peak performance of its employees constantly to compete in the market effectively (Prasad 2006).

A set of outcome doesn't refer to personal qualities, characteristics or competencies of the performer and produced during a certain period of job can be referred as performance. The evaluation of performance of an employee discloses an individual's contribution in achieving organization's objectives. A person's performance cannot be improved unless he is given feedback on his action's results. Feedback must be provided continuously for corrective actions and it should cover both positive and negative aspects (Biswajeet 2009).

In human capital formation, education plays an important role. It enhances the efficiency and productivity of an individual so we get a skilled manpower that leads the economy towards the way to sustainable economic development. The condition of education system is not hopeful in Pakistan like other developing countries. The poor performance of this sector can be predicted as there is lack of suitable teaching materials, low enrolment tariff at the primary level, deficiency of trained teachers, broad differences between regions and gender and poor physical infrastructure.

The purpose of this study is to evaluate the performance appraisal system for teachers in private schools and elaborate the problems align with this system. The Educators School has been taken as a case study for this research.

The Educators school system is a project of the Beaconhouse school system that is working in eight countries as an international private school system. The Educators school was established in 2002. Now it is operating in more than 200 countries with more than 600 branches and spreading its unique learning experience. Now it is also opening its franchises outside Pakistan such as in Saudi Arabia. Following are the research objectives of this study:

1. To evaluate the teacher's evaluation system of The Educators School.

2. To identify the reasons which are affecting the teacher's performance in The Educators School.

3. To suggest The Educators School a better system of teacher's evaluation. 


\section{Literature Review:}

Every individual's performance who is working in an organization has its own importance towards its success. In this dynamic environment, it is very important for an organization survival to use their resources effectively and efficiently. And to achieve organizational goal, the evaluation of resources is also very important. As most valuable and complicated resource of an organization is human resource, so it is important that the organization conduct performance appraisal of the HR which is essential and complex. (Toppo \& Prusty, 2012)

\subsection{Performance appraisal:}

Beach (1980) defined performance appraisal (PA) as a systematic evaluation of a person according to his job performance and his capability for development. A continuous process through which we can identify, measure and improve the employee's performance in an organization is performance appraisal. Offering career development, employee's achievements recognition and providing them regular feedback are some of the practices of this process (Aguinis, 2007; Lansbury, 1988)

\subsection{Performance management system:}

According to Pareek and Rao (2006) the aim of Performance management (PM) is to create a culture in which continuous improvement of business processes are the responsibility of individuals and teams along with their own skills improvement and assistance provided by effectual leadership. Hence the objective of PA and PM is to improve individual's performance. Both are human resource developing instruments but different in scope. To achieve the employee's full capacity which will be in benefit of both employee and organization is the main objective of PM system. The full potential of an employee can be gain by defining them the organization expectation in terms of expected behavior, tasks, responsibilities and required proficiency. (Armstrong, 2006)

Wilson (2005) added that PM is a set of processes. It is neither a single step process nor a technique. It includes employee's knowledge about their manager's expectations, their motivational level to perform up to the mark, counseling and their performance evaluation aimed at identification of their weak areas of performance where improvement is required.

\subsection{From PA to PM system:}

Tripati (2005) mentioned that the shortcoming of the PA system is one of the important reason of the organization to shift from PA to PM even though the purpose of both are same that is to develop employee's performance by classification of their strengths and weaknesses to lead for formulation of appropriate training and development program.

When we compare PA and PM system the main difference is that PA sets job standards and on the basis of these set standards past performance of employee is evaluated. PA is used as a tool which is used to evaluate an employee and mangers are encouraged to make subjective judgment against the job standards which were predetermined. While on the other hand PM system focuses on managing immediate performance to ensure that the performance must reach at desired level. It is an ongoing process in which the performance of an employee is 
well managed so that the set targets can be achieved on time without evaluation or corrective action at some point in future (Armstrong, 2006).

\subsection{Need for PM system:}

According to Bourne et al (2003) Organizational objectives can be achieved through a better PM system. According to practitioners, it is a corporate, business or an enterprise PM system. It shows that performance management principles are being used at each level of the organization. The term corporate performance management is used to make a distinction between the individual and organizational performance management.

De-Waal (2006) added that the best approach to gain good results is performance management. Due to this many of the profit as well as non-profit organizations are trying to implement a PM system in their organizations so that they can gain better outcomes in a dynamic and changing environment.

If you want to create a PM system in an organization few things you have to take in account i.e. job performance should be clearly understood as a measuring tool of performance and through a fair and accurate performance evaluation, rewards should be given to the employees along with the development opportunities and acceptable feedback should also be provided to employees. The PM system will be able to efficiently work in an organization if it is completed and redefined. (Decramer et al,2008)

In most of the organizations, managers are the one and only source to evaluate employee's performance but before giving them the feedback they are ask to self-assess them.

In organization when it is asked from HR that what they think about performance appraisal purposes they said that the performance appraisal information is used to give promotions and recognition to employees and for salary purposes. None of them talk about its development approach. . (Dargham, 2008)

Organizational performance and the attention given to management control have a clear and strong relationship. Both dimensions of management control i.e. instrumental and behavioral should be improved. Organization should not only improve these dimensions of management style but also do this in order to improve the overall organization's performance. Thus the study of Waal (2010) has identified some instrumental and behavioral dimensions. Instrumental dimensions are content, alignment, integrity, responsibility structure, manageability. Behavioral dimensions are communication, management style, action orientation and accountability. In order to get sustainable performance, organization should focus on these dimensions.

Cokins (2004) stressed that we can get better results from performance appraisal only when organization's employees have trust on that system and in a transparent way they are involved in mutual goal setting. Mani (2002) has mentioned that when employees are satisfied with their manager and has reliance on performance appraisal system only then they perceive it as a better management decision tool. Only on the basis program's procedure, employees don't perceive this system as fair. 
Roberts (2003) supported the idea that if the results of this system are acceptable for employees and they think it as fair and transparent and have trust on this system otherwise the implementation of this system will be useless and ineffective. Dargham (2008) research observed five different types of problem generated by the appraisal systems i.e. The use of conflicting criterion which may lead to unenthusiastic mind-set toward the PA system, shortage of tools seeking to improve the PA system, an unfair perceived PA system, not having the support of senior management and finally untrained appraisers who require communication skills and as a result are not capable of conducting an effective feedback.

The research findings pointed out many areas which need to be improved like an open and sincere feedback, a fair process, a structure in which enhancement in PA may be facilitate, the use of clear evaluation criteria and finally senior management support.

Managers have to manage their own performance first if they want to be a good performance manager. Research of Aslam and Sarwar (2010) explored that the company manager should be trained first about the system and implementation of that system which company own HR managers or third party experts are going to introduce in the organization. Gaining the line manager's commitment on PMS is one of the major problems. It has to be done even though it takes a lot of time and effort. This problem can be solved by the top executives as they can make PMS a part of manager's job description and realize them that it is the essential part of their job. Line managers should be trained and motivated as they are directly responsible for the implementation of PMS in their relevant department and also responsible for employee's motivation in this regard.

\subsection{Education in Pakistan:}

Education plays a vital role in socio-economic development. A most reason of less development in poor countries is their poor quality of educational system. In spite of the fact that the government of Pakistan has introduced radical measure in enriching the quality as well as the quantity of education, the quality of education in Pakistan is turning down. Teacher's quality especially at primary level is still doubtful. If we want to improve the quality of education then we have to transform our teachers first. So in the public sector to improve teacher's quality a series of education reforms were initiated but the vision appears to be narrow. Therefore they failed to make any significant impact on teaching process and teacher's quality. In the long run it additionally affects the education's quality offered in school. New challenges are being faced by education system in Pakistan. It should be developed according to other developing countries in Pakistan. (Memon, 2007)

\subsection{Performance management system in educational institutions:}

Now a days it is becoming so difficult to imagine educational life without the use of performance indicators as a way of managing as well as improving education performance in school, colleges and universities. However these are different from the previous practices e.g. providing data on success rates of examination. Monitor systems, identify trends and then promote changes are some of the practices which policy makers do by using the data collected on the execution of education system. Current form of Performance management, 
though, has origins in concern about education's underperformance in an increasingly competitive global economic environment. (Ozga, 2003)

According to Simmons \& Iles in knowledge-based organizations, 'Intellectual capital' is the key asset and the value of this human base asset can be enhance and maintain through a good performance management system. In this type of organizations it is very difficult to manage the professionals in view of the level of good judgment and autonomy in their work roles and their loyalty may be related to particular code of conduct or personal development. In higher education, academic staff constitutes a group of knowledge-based workers who are very dedicated towards the effectiveness of the operations of their institutions. That's why the managers working in this type of organizations are responsible to design and operate a performance management system that not only motivate academic staff but also align their hard work with the objectives of institution.

Performance management considered necessary to be an integrated mutual effort that draw on the capability and experiences of both academic and supporting staff and transcend traditional differences between academic and supporting staff in higher education. To make it successful, the development of these complex systems needs to draw on the know-how of management, supporting and academic staff.

The results show that in higher education the typical approaches of performance management don't work well. So, the models and approaches of the performance management systems need to be developed according to the needs and vision of the higher education systems and should be followed by the introduction of the system that allows for a process of systematic adjustment and transformation of institution. (Mapesela \& Strydom, n.d.)

According to Hattie (2003) Students who are educate by the expert educators reveal an understanding of concepts delivered in the instructions that is more logical, more integrated, and have a high level of concept than the understanding of the other students who are not educated by the experts. So, educational institutes have to train their faculty members to enhance their performance level and also in order to provide quality education to students.

Donald et al (2005) added that teacher's effectiveness can be affected by the institution's curriculum, resources and/or administrative leadership.

Sarwar et al (2010) said that there are many factors due to which the performance of the employees gets affected especially beginning teachers. Those factors are overburden, ambiguous job description, lack of teaching experience, communication gap between a senior and a junior employee, maintaining classroom discipline, strict evaluation, student counseling, assessing student work, deficiency of materials and supplies, and least expectations for the teaching career.

The results of Rasheed et al (2010) study added that the responsibility of a administrator is very important in motivation and retention of employees and it is in the hand of supervisor that how well he encourage its employees to get the best results by using their full potential but during survey he observed a communication gap can that should be eliminated. So the author strongly recommends that to get a good administrator it is compulsory to train them. It 
is also seen that the workload on the teachers is so high, they have to take lectures as well as perform administrative activities due to which their teaching and research is get affected so it should be reduced to get good results. Recognition and continuous feedback must be provided to teachers and a sense of appreciation can be given by involving them in departmental decision making

Rasheed et al (2011) conduct a research on performance management system for teachers of a university. The findings of the study suggest that through recognition, feedback, performance review meetings and participation in performance planning are some of the important factors which improve the quality of the system and also its impact on teachers. Findings also show that supervisor (HOD) role on the performance of employees (Teachers), getting good results from them and developing their capabilities is very important. So, the supervisor should be well trained and have complete knowledge about the performance appraisal so that he can conduct PA very well and also according to the beliefs of up to date appraisal systems.

Farooq et al (2011) stressed that the main duty of teachers is to teach their students efficiently so that they will be able to get good marks and sustain good performance in their academic record. To accomplish this goal it is obligatory for the facilitators to recognize the factors that will add in their academic record.

Jahangir (1988) believed that the teacher's performance can be evaluate on the basis of four teaching behavior i.e. personality, interaction with students, intellect and teaching techniques.

While seven performance aspects are identified by Ferris et al., (1988). These are effectiveness in presenting subject matter, self-improvement, poise, preparation and planning, relations with students, relations with parents \& community and relations with other staff.

Akram (2010) suggests that a significant improvement in performance of teacher can be brought if they improve their performance on the factors like subject mastery, methods of teaching, mind-set toward students and personal uniqueness.

\section{Research Methodology:}

\subsection{Research Design:}

The purpose of this study is to evaluate the performance management system of The Educators School. The research type used to evaluate this is exploratory research. According to Kumar, exploratory research is basically help to examine any problem with appropriate hypothesis.

The population selected was all teachers and admin staff of The Educators School. All genders, ages and language groups are included. To collect the primary data, self administered questionnaire are used as a key source.

\subsection{Research Strategy:}

The target population for this research is the teaching and admin staff of The Educators School. The population size of The Educators School is small so all the population is included for this research. In this research, researcher is going to evaluate the current 
performance evaluation system of The Educators School and also gave a better evaluation system which covers the maximum weak aspects of the current system they are using.

\subsection{Research tool:}

In order to reach at a fair conclusion qualitative as well as quantitative data is collected. Qualitative data is collected in form of in-depth interviews while quantitative data is collected in form of questionnaire. Questionnaire was developed to evaluate the performance of teachers and also for admin staff that how they evaluate the performance of teachers. Questionnaire items help in identifying the performance of teachers and the results will be checked with the help of statistical tool. While interview questions also help in evaluating the performance of the teachers and the results will be checked with the help of content analysis.

\section{Data Collection and Analysis:}

The target population included all the employees of The Educators School Fatima Campus. 20 questionnaires were distributed and all were received back. Sampled population consisted of 18 females and 2 males.

Data is collected from the teaching staff of the school. Performance appraisal for the teachers is conducted director or principal annually. Performance appraisal form is same for all teachers.

\section{What is the purpose of performance appraisal system in The Educators School?}

Purpose of Performance appraisal system

\begin{tabular}{|rl|r|r|r|r|}
\hline & Frequency & Percent & Valid Percent & $\begin{array}{c}\text { Cumulative } \\
\text { Percent }\end{array}$ \\
\hline \multirow{2}{*}{ Valid Salary } & salary and training needs & 1 & 5.0 & 5.0 & 5.0 \\
& Total & 19 & 95.0 & 95.0 & 100.0 \\
\hline
\end{tabular}

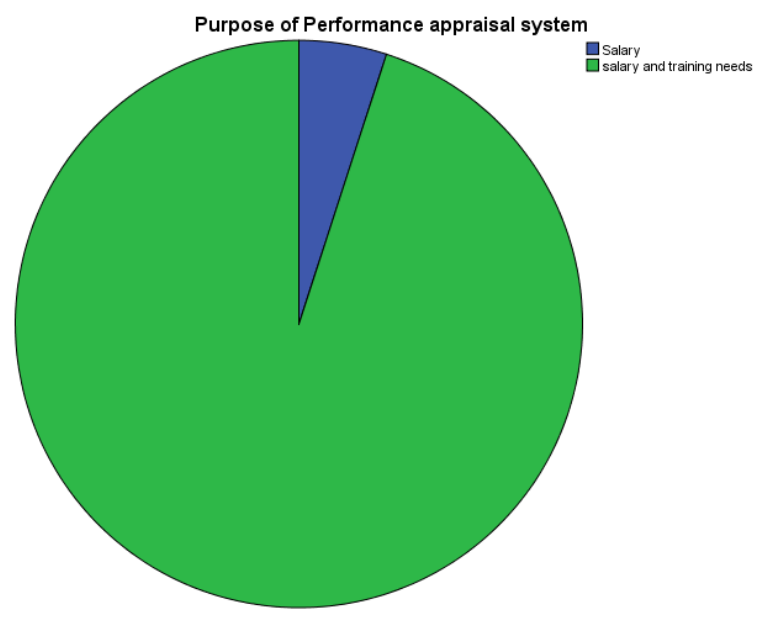

95\% of the teachers think that the purpose of performance appraisal is to decide the salary 


\section{Macrothink}

Journal of Public Administration and Governance ISSN 2161-7104 2013, Vol. 3, No. 4

and training needs of an employee. While 5\% think that it is used just to increase or decrease the salary of the teachers.

Are the teachers are allowed to participate in setting the standards for measuring performance?

\section{Participation in setting standards for Performance}

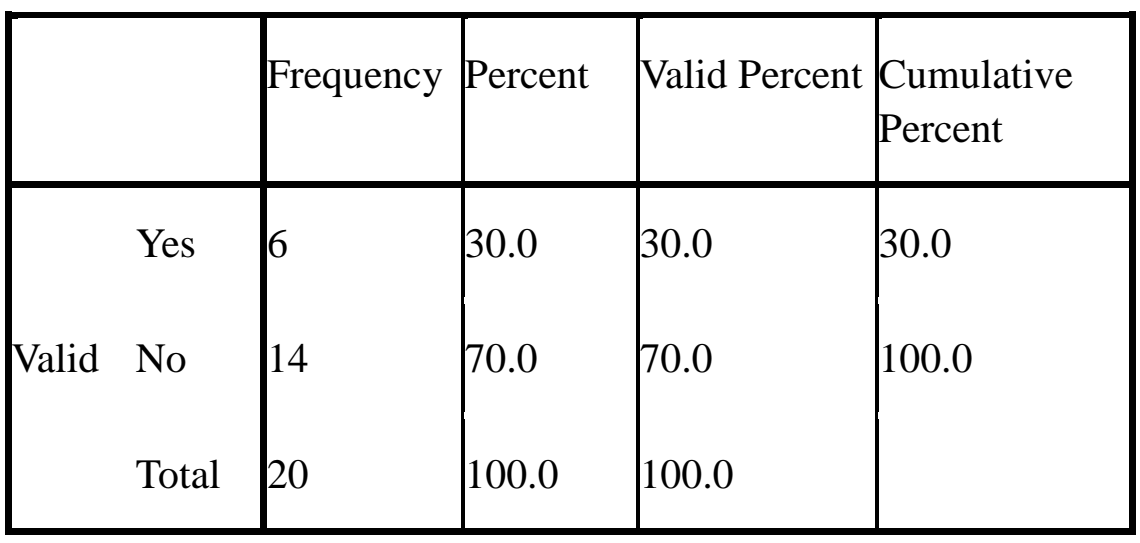

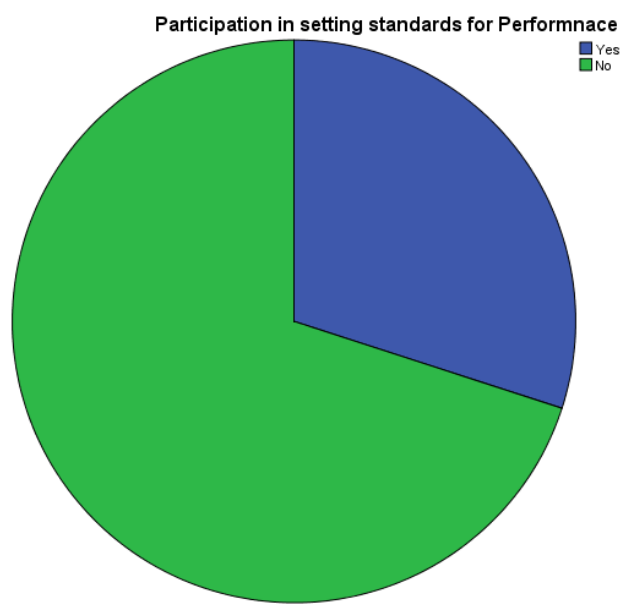

This question addresses the participation of teachers in setting standards for performance. $70 \%$ of the employees think that they are not participated in setting standards for performance but $30 \%$ of the teachers think that their opinion is considered while setting the standards for performance.

Do you think the Director/Principal meet with each teacher for discussion on the planning of the teacher's performance appraisal process?

In this question teachers were asked whether they are being discussed while planning the teacher's performance appraisal process. All of the employees give same response that they are not being discussed as it is planned by the Head office and it is confidential. 


\section{Macrothink}

Are the teacher's career objectives and strategy to maximize their career potential considered during performance appraisal?

In response to this, $80 \%$ of the teachers think that their career objectives and strategy to maximize their career potential considered during performance appraisal while $20 \%$ disagree with this statement.

\section{Is the opinion of colleagues and students considered for performance appraisal?}

This question focuses on whether the opinion of colleagues and students are considered in performance appraisal. 85\% of the teachers respond that yes their colleagues and students opinion is also considered in their performance appraisal while $15 \%$ denied this.

During the evaluation, which of the following factors are considered by the Director/Principal?

\section{Factors considered during evaluation}

\begin{tabular}{|l|l|l|l|l|}
\hline & Frequency & Percent & Valid Percent & $\begin{array}{l}\text { Cumulative } \\
\text { Percent }\end{array}$ \\
\hline $\begin{array}{l}\text { Teachers attainment of } \\
\text { previously set goals and } \\
\text { objectives }\end{array}$ & 20 & 100.0 & 100.0 & 100.0 \\
\hline
\end{tabular}

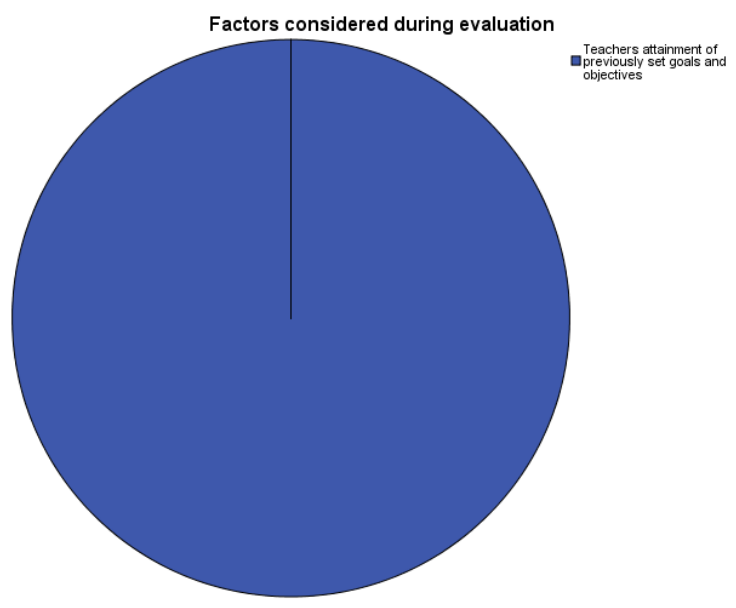

Different factors options were given to teachers i.e. Experience of the teacher, Training of the teacher, job description and teacher's attainment of previously set goals and objectives on the basis of which their director or principal evaluate them. All of them respond that their performance is evaluated on the basis of teacher's attainment of previously set goals and objectives. 


MlMacrothink

Is the teacher asked to perform an evaluation of his/her own performance?

In response to this question, all teachers gave same response that they are not self-assessed.

Is there a performance appraisal review and feedback session occurring in the school?

\section{PA review and feedback}

\begin{tabular}{|ll|l|l|l|l|}
\hline & Frequency & Percent & Valid Percent & $\begin{array}{l}\text { Cumulative } \\
\text { Percent }\end{array}$ \\
\hline Yes & 16 & 80.0 & 80.0 & 80.0 \\
Valid No & 4 & 20.0 & 20.0 & 100.0 \\
& Total & 20 & 100.0 & 100.0 & \\
\hline
\end{tabular}

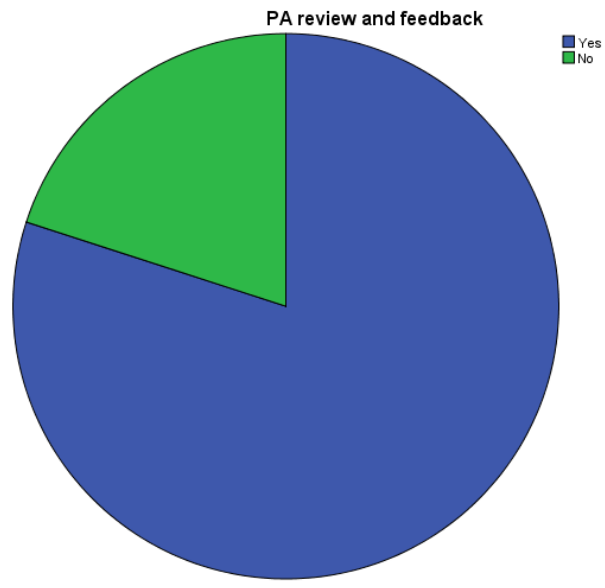

$80 \%$ of the teachers agree with this statement that performance appraisal review and feedback occur in this school while $20 \%$ teachers disagree with this statement.

Does the Director/Principal discuss the assessment with the teacher after the appraisal is over? 


\section{Macrothink

\section{Discussion after appraisal}

\begin{tabular}{|c|c|c|c|c|c|}
\hline & & Frequency & Percent & Valid Percent & $\begin{array}{l}\text { Cumulative } \\
\text { Percent }\end{array}$ \\
\hline \multirow{3}{*}{ Valid } & Yes & 17 & 85.0 & 85.0 & 85.0 \\
\hline & No & 3 & 15.0 & 15.0 & 100.0 \\
\hline & Total & 20 & 100.0 & 100.0 & \\
\hline
\end{tabular}

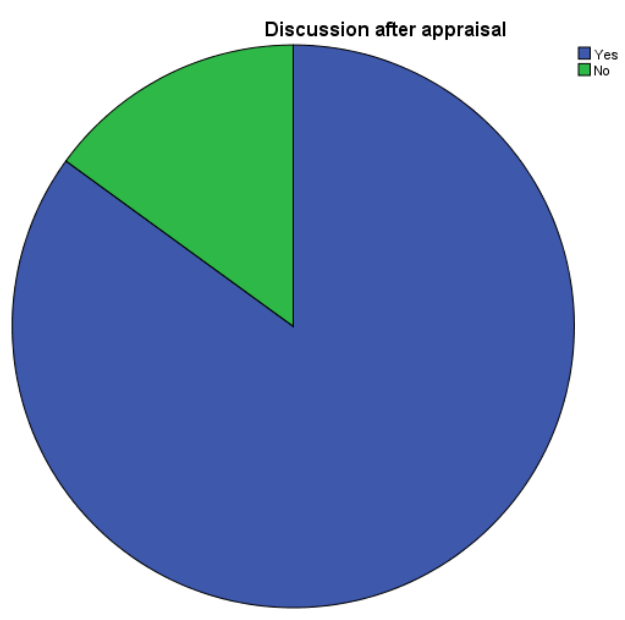

$85 \%$ of the respondents said that they are being discussed about their performance as the appraisal is over while $15 \%$ respondents said that they are not being discussed.

Does the Director/Principal provide coaching if it is needed as per the performance appraisal?

All the respondents agree with this statement that their senior provide coaching to them if it is needed as per the performance appraisal. 


\section{Macrothink}

Director/Principal discusses with his/her teachers both positive and negative aspects of the teacher's performance?

Thorough discussion of performance

\begin{tabular}{|c|c|c|c|c|c|}
\hline & & Frequency & Percent & Valid Percent & $\begin{array}{c}\text { Cumulative } \\
\text { Percent }\end{array}$ \\
\hline \multirow{4}{*}{ Valid } & Yes & 8 & 40.0 & 40.0 & 40.0 \\
\hline & No & 5 & 25.0 & 25.0 & 65.0 \\
\hline & Sometimes & 7 & 35.0 & 35.0 & 100.0 \\
\hline & Total & 20 & 100.0 & 100.0 & \\
\hline
\end{tabular}

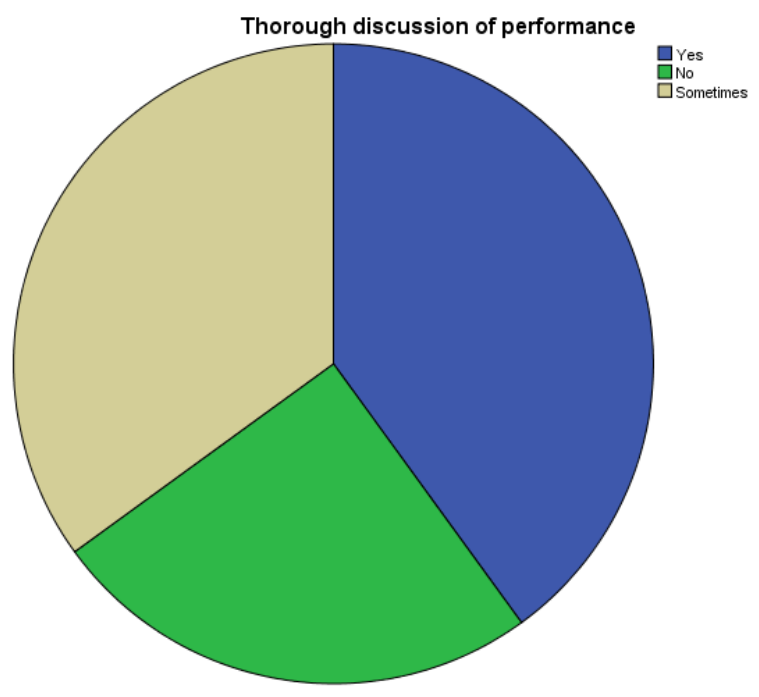

$40 \%$ of the respondents said that they are being told about their positive as well as negative aspects of performance and 35\% said that sometime they do but sometime they don't while $25 \%$ of the respondents said that they are not told about their positive and negative aspects of performance.

Performance appraisal in The Educators focuses on achieving the goals, objectives and key responsibilities of a teacher's job?

$50 \%$ of the respondents strongly agree with this statement remaining $50 \%$ agree with this statement that performance appraisal in The Educators school focuses on achieving the goals, objectives and key responsibilities of a teacher's job. 


MlMacrothink

Performance appraisal has an impact on effective job performance in The Educators?

Impact on high job performance

\begin{tabular}{|c|l|l|l|l|}
\hline & Frequency & Percent & Valid Percent & $\begin{array}{l}\text { Cumulative } \\
\text { Percent }\end{array}$ \\
\hline Strongly agree & 6 & 30.0 & 30.0 & 30.0 \\
Valid Agree & 14 & 70.0 & 70.0 & 100.0 \\
Total & 20 & 100.0 & 100.0 & \\
\hline
\end{tabular}

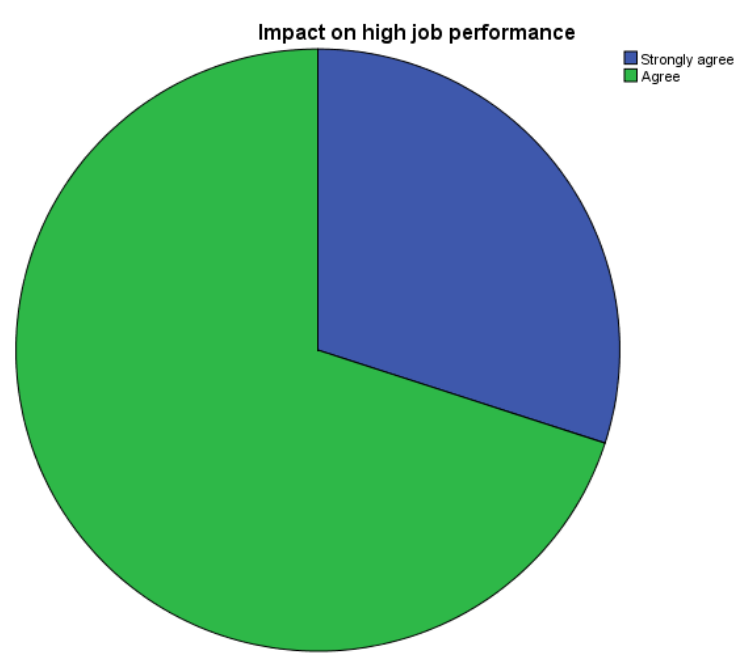

$30 \%$ of the respondents strongly agree while remaining $70 \%$ agree with this statement that performance appraisal has an impact on effective job performance in The Educators.

Performance Appraisal Program increases professional development of teachers.

All respondents agree with this statement that performance appraisal program increases professional development of teachers.

Performance Appraisal Program helps clarifying job duties and responsibilities of teachers?

All of the respondents think that performance appraisal program helps in clarifying job duties and responsibilities of teachers. 


\section{Macrothink}

Performance Appraisal Program is used as a tool to identify learning and development needs of teachers?

Tool to identify learning and development needs

\begin{tabular}{|c|l|l|l|l|}
\hline & Frequency & Percent & Valid Percent & $\begin{array}{l}\text { Cumulative } \\
\text { Percent }\end{array}$ \\
\hline Strongly agree & 8 & 40.0 & 40.0 & 40.0 \\
Valid Agree & 12 & 60.0 & 60.0 & 100.0 \\
Total & 20 & 100.0 & 100.0 & \\
\hline
\end{tabular}

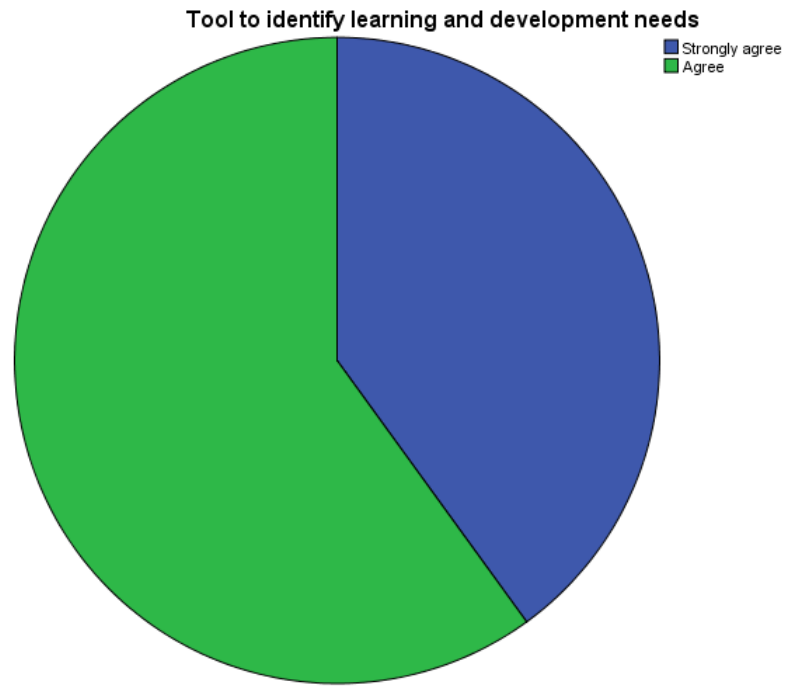

All of the respondents strongly agree with this statement that performance appraisal system is used as a tool to identify the learning and development needs of teachers.

\section{Conclusion:}

Education plays an important role in socio-economic development. One of the most important reasons of less growth of poor countries is their poor quality education. In Pakistan education quality is decreasing even though the government is trying to uplift that but at primary level the teacher's quality is still questionable. Without their transformation it is impossible to transform the overall education system. The basic role of this study is to analyze the performance appraisal system of The Educators School. The findings of the study are as follows:

1. The study shows that the system used in The Educators School is performance appraisal system. In which their development is not considered. There is no 
continuous feedback. Feedback is given at the end of the session.

2. The performance appraisal is used for salary increment or decrement and also for training. But training is provided after appraisal which is conducted at the end of the year.

3. Teachers are not involved during planning of the performance appraisal system. It is provided by Head Office to all sub campuses.

4. Performance appraisal is not discussed with teachers, it remains confidential due to which they doesn't know that on which basis they are being evaluated.

5. The negative and positive points of teachers are sometime discussed with them but sometime not. Due to improper feedback session confusions arises in teachers mind and they got de-motivated.

6. There is no concept of self-assessment in the performance appraisal system. Principal of the school evaluate teachers.

Findings have shown the important role of Principal in conducting appraisal system so they should be trained well for conducting performance appraisal system.

\section{Recommendations:}

On the basis of above discussions researcher gave following recommendations to improve the performance appraisal system in The Educators School:

1. There should be a continuous feedback system in school. As a weakness is identified in teachers, they will be told so that they can overcome that weakness.

2. Appraisal should not be used only for the purpose of salary increment but it can also be used for development of teachers.

3. Appraisal should be open so that everyone knows why they are evaluated good or poor so that they can strengthen their strengths and overcome their weaknesses.

4. They should share every teacher's positive points with other teachers so that all of them try to develop that skill in themselves and the teacher whose strength is discussed in front of all will feel appreciated and get motivated to improve his/her performance more.

5. Training should be provided not after the appraisal but it should be provided as it is identified in teachers so that their performance can be improved continuously.

\section{References:}

1. Aguinis H (2007). Performance management. Printice Hall. London.

2. AKRAM, M. J. (2010). FACTORS AFFECTING THE PERFORMANCE OF. University Institute of Education and Research .

3. Aslam HD, Sarwar S (2010). Improving Performance Management Practices in IT 


\section{Macrothink}

Journal of Public Administration and Governance ISSN 2161-7104 2013, Vol. 3, No. 4

Firms of Pakistan. J. Manage. Res., 02(3):1-15

4. B. Pattanayak, Human Resource Management (PHI Learning Private Limited, 2009).

5. Bourne, M., Franco, M. and Wilkes, J. (2003). "Corporate performance management", Measuring Business Excellence, 7(3):15-21.

6. Cokins G (2004). Performance management. Finding the missing pieces and closing the intelligence gap. John Wiley and Sons. Australia.

7. Dargham, N. A. (2008). EFFECTIVE MANAGEMENT OF THE PERFORMANCE APPRAISAL PROCESS IN LEBANON: AN EXPLORATORY STUDY.

8. Decramer, A., Christiaens, J., \& Vanderstraeten, A. (2008 ). Implementation Dynamics of Performance Management in Higher Education.

9. Donald Boyd, P. G. (2005). How Changes in Entry Requirements Alter the Teacher Workforce and Affect Student Achievement. New york.

10. Farooq, M., Chaudhry, A., Shafiq, M., \& Berhanu, G. (2011). FACTORS AFFECTING STUDENTS' QUALITY OF ACADEMIC PERFORMANCE: A CASE OF SECONDARY SCHOOL LEVEL. Journal of Quality and Technology Management, 07(2):01-14.

11. Ferris, G.R., Bergin, T.G., and S. Wayne. (1988). Personal Characteristics, Job Performance and Absenteeism of Public School Teachers. Journal of Applied Social Psychology, 18(7): 552-563.

12. Hattie, J. (2003). Teachers Make a Difference What is the research evidence? Auckland: Australian Council for Educational Research.

13. Jahangir, F.S. (1988). Student Evaluation of Their Teachers' Performance. Pakistan Psychological Studies, 27-30.

14. Lansbury R (1988). Performance Management. A Process Approach. Hum. Resour. Manag. Australia, 46-55.

15. L.M. Prasad, Human Resource Management (Sultan Chand \& Sons: Educational Publishers, 2006).

16. Mani B (2002). Performance Appraisal Systems. Productivity and Motivation. A Case Study. Pub. Pers. Manag., 32 (1):141-159.

17. Mapesela, M., \& Strydom, F. (n.d.). Performance Management of academic staff in South African higher education: a developmental research project .

18. Memon, G. R. (2007). Education in Pakistan: The Key Issues, Problems and The. Journal of Management and Social Sciences , 47-55.

19. Michael Armstrong (2006). Human Resource Management Practice, Kogan Page Ltd. Landon and Philadelphia. 
20. Ozga, J. (2003). Measuring \& Managing Performance in Education.

21. P.C. Tripathi (2006). Human Resource Development Sultan Chand \& Sons: Educational Publishers.

22. Rasheed MI, Sarwar S, Aslam HD. (2010). Motivational Issues for Teachers' in Higher Education: A Critical Case of IUB. J. Manag. Res., 02(2):1-23.

23. Rasheed MI, Sarwar S, Aslam HD. (2011). A critical analysis of performance appraisal system for teachers in public sector universities of Pakistan: A case study of the Islamia University of Bahawalpur. African Journal of Business Management, 5(9):3735-3744.

24. Roberts G (2003). Employee Performance Appraisal System Par-ticipation.A Technique that Works. Pub. Pers. Manag., 32 (1): 89-98.

25. S. Dale Beach, Personnel: The management of people at work (Macmillan Publishing Company, 1980).

26. Sarwar S, Aslam HD, Rasheed MI (2010). Hindering Factors of Beginning Teachers High Performance in Higher Education A Case Study of IUB The Islamia University of Bahawalpur. Int. J. Educ., 02(1): 1-12.

27. Simmons, J., \& Iles, P. (n.d.). Performance Appraisals in Knowledge-Based Organisations: implications for Management Education. The International Journal of Management Education, 03-18.

28. Toppo, M. L., \& Prusty, D. T. (2012). From Performance Appraisal to Performance Management. IOSR Journal of Business and Management (IOSRJBM), 3(5):01-06.

29. U. Pareek and T.V. Rao (2006). Designing and Managing Human Resource System, Oxford and IBH Publishing Co. Pvt. Ltd.

30. Waal AA (2006). 'The Role of Behavioral Factors and National Cultures in Creating Effective Performance management systems', Syst. Practice Action Res., 19(1): 61-79.

31. Waal, A. A. (2010). Performance-driven behavior as the key to improved organizational performance. MEASURING BUSINESS EXCELLENCE , 14(1):79-95.

32. Wilson J P (2005). Human Resource Development: 2nd edition. Kogan Page. London. 